\title{
AUDIT IN THE STATE ECONOMIC SECURITY SYSTEM
}

\author{
Karina Nazarova ${ }^{1}$, Volodimir Hordopolov ${ }^{1}$, Tetiana Kopotiienko ${ }^{1}$, Viktoriia Miniailo ${ }^{1}$, \\ Viktor Koval'2, Yuliia Diachenko ${ }^{3}$ \\ ${ }^{1}$ Kyiv National University of Trade and Economics, 19 Kyoto str., Kyiv, Ukraine, 02156 \\ ${ }^{2}$ Odessa Institute of Trade and Economics of Kyiv National University of Trade and Economics, 6 \\ Inglezi str., Odessa, Ukraine, 65070 \\ ${ }^{3}$ Odessa National Academy of Food Technologies, 112 Kanatna str., Odessa, Ukraine, 65039
}

Received 1308 2019, Accepted 02092019

In the research it is proved that constant and progressive development of any country is impossible without providing economic and social security processes. The aim of the article is to determine the state and development trends of state and independent professional audit as a key imperative for the formation of economic security. It is justified that due to financial globalization, complexity and versatility of both interstate and domestic correlation, economy development dynamics are sensitive to crisis occurrences. It is concluded that nowadays due to complicated economic and social conditions questions of justification priorities of state and independent audit development during the formation of state's economic security and the definition of alternative methods of business security are up to date. The state, dynamics and development trends of state and independent external audit were analyzed according to modern economy state. It was defined that audit develops through several key directions that are important for providing the economic security. To increase the positive value of audit in providing the economy security of the state to organizations alternative methods of business protection have to be used alongside with standard audit methods.

Key words: audit, economic security, effectiveness, audit services, forensic.

JEL Codes: F52 H83.

\section{Introduction}

Financial system globalization, complexity of economic both interstate and domestic relations, increase in role and quantity of diverse financial instruments and general development in country's economy is impossible without state and independent audit procedures during this important economy processes.

Copyright (C) 2019 The Authors. Published by Vytautas Magnus University. This is an open-access article distributed under the terms of the Creative Commons Attribution-NonCommercial 4.0 (CC BYNC 4.0) license, which permits unrestricted use, distribution, and reproduction in any medium, provided the original author and source are credited. The material cannot be used for commercial purposes. 
In terms of open economy, the limitation of economic resources owned by the national economy alongside with private sector actualizes the significance of audit according to effective usage of public finances, transparency of a budget process and protection of the interests of financial and other economic information users. Accelerated usage of modern technologies in management processes forms increased demands to audit questions for financial field as well as for ecology, technical, custom and tax audit. Lately, the scientific community discusses the questions of formation and effective politics realization in the field of economic security of the state. The implementation of methods and technologies into the field of development and execution of administrative politics in the economic security of the state will give the government a possibility to concentrate on examination of strategically important decisions due to adequate democratic administration while being in conditions of deficiency in financial, material and time resources.

\section{Literature review}

Theoretical, methodological and praxeological principles of state's economic security development are a subject of scientific researches of numerous domestic and foreign authors. Meiss et al. (2017) focus their attention on state's financial security as a component of economic security. According to mentioned scientists, state financial control has the biggest influence on state's financial security. Based on this, scientists highlighted the features of state's financial control as a factor that provides country's financial security. They also grouped the disadvantages and factors that influence the state's control system. According to this, vectors of state's financial control development based on system, functional, administrative, organizational and methodological approaches were proposed.

Correctly chosen approach to state's economic security management allows to minimize possible risks and to provide its proper level. The formation of the metric system for management activities results and coordination of corporate relations are one of the ways to improve this process. It is promoted by its standardization at the entity level. Particularly, theoretical and practical aspects and specifics of economic security management on the micro level are displayed in the researches of Moscalenko et al. (2015). Based on this, the typical problems that may negatively influence the entity's economic security management were identified by the authors. Thus, the propositions that standardize the process as a direction to improvement were formed.

A significant problem which nowadays blocks the process of constructing the efficient economic security system is its shadowing. An increase in the level of economy shadowing in Ukraine is determined by a number of different factors. Hubareva et al. 
(2016) include imperfection of anticorruption and judicial reforms, tax system in Ukraine (both in the legislation forming and tax collecting from payers), fund withdrawal from Ukraine to the list of the factors. Based on the cognitive approach, the authors performed a simulation of the impact of adverse factors on the state's economic security and generated suggestions that should promote the increase of its level. The main two of them are de-offshore of the economy and a decrease in tax burden.

The questions of providing economic security are the research objective both on the state and entity levels and on the meso level. Thus, Trusova and Klymenko (2016) in the research clarify the principles of forming the economic security on the meso level, display organizational, legal, economic specifics of forming the economic policy in Ukrainian regions and suggest the methods to improve the process of its realizations to provide an appropriate level of country's economic security. Besides the surveillance function, state audit is considered as a monitoring in the provision of country's economic security. Therefore Chen (2011) is considering state audit as a scientific concept of country's economic security based on special audit investigations.

Particularly, researches of state financial audit with an opportunity to transform it into forensic were examined by Deb (2018), who allocated corruption risks of accounting and essential influence on the process of state audit.

Theoretical, methodical, organizational and practical questions of auditing have become a subject of the scientific interest of a large number of scientists, such as Khovrak \& Kozyarchuk (2017), Fabiianska (2018), Nazarova et al. (2018), Drogalas et al. (2019). Admitting the validity of scientific achievements, should be noted that country's economy functioning stipulate that the audit provides realization of important functions that form the appropriate level of the economic security on the micro and macro levels. Herewith, the questions of justification of the state and governmental audit development priorities while forming state's economic security, defining the alternative ways of business protection are still relevant. The objective is to determinate the state and tendencies of state and independent professional audit development in realties of modern economic state; to justify the development prospectives as a key imperative of the economic security formation.

\section{Results and discussion}

Dynamism and instability of different factors that influence the state's economy determine that the national security term is one of the key terms in the state management. National security represents a symbiosis of state interests on macro-, micro- and global levels, while being characterized as a system of a complex content. It is an instrument for influencing the formation of economic relations of country and 
forms the basis for a sustainable development. One of the most common definition of the economic security is its interpretation as a state of the security of the vital interests against external and internal dangers Masaraki et al. (2010) include the increase in goods and services competitiveness, the decrease in state's financial dependence from foreign lending, solvency strengthening in terms of fulfillment of financial commitments and international obligations in the trade and economy sphere to the main tasks of the economic security.

The state of the economic security can be directly or indirectly defined by a number of economic indexes that are fundamental while positioning Ukraine in the international ratings. Particularly, in the economic liberty rating that is published by American analytics centre Heritage Foundation, in 2018 Ukraine obtained $150^{\text {th }}$ place among 186 countries (Heritage Foundation, 2019).

Amongst European countries Ukraine obtained the $44^{\text {th }}$ place that is the lowest. For a comparison, in 2016 Ukraine obtained $162^{\text {nd }}$ place in Index of economic liberty rating. According to the given information, Ukraine improved its positions in 8 out of 12 indexes, gaining 51,9 points out of 100 . The indexes of monetary freedom and freedom of investment significantly improved. However, even though the offsets are positive, Ukraine is still in the number of countries defined as "mostly not free".

Such negative events as the annexation of the Crimea and the military conflicts on the east have become a serious threat to the Ukraine's economic security. Despite a number of improvements towards democratization, the rating creators emphasized on the urgency to privatize the national organizations, improve of the legislative framework, overcome the corruption in the judiciary and to attract investors.

Based on the main state's economic security feature as systematic, the authors Masaraki et al. (2010) suggested examining this definition through levels and objectives of the economic security that consist of: global level that forms national household; macro level that displays the national economy; meso level that is a combination of field economy, infrastructure economy and region economy; micro level that consists of entity economy and households economy.

At each of these levels, economic security determines the stability of functioning at given parameters of the production function, which mainly depends on the parameters of labor and capital (Koval et al., 2018).

Agreeing with the outlined position, the complexity of the only mechanism formation that completes indicated tasks on every level of state's economic security. Different instruments and strategies of influence on economic security should be used on every level. Without changing the importance of the state politics, we consider it necessary to pay attention to the micro level that is represented by economies of the entities and households. After all, providing the proper level of entity's economic 
security will have results displayed as an increase of level of financial goodness, gross domestic product growth, an increase in the amount of tax revenue to the budget that will lead to the strengthening of state's economic positions.

To complete this task conducting analytical researches is as important as granting comprehensive and convincing reasoning to justify recommendations about present problems on the state's economic security field.

For the purpose of stabilization of financial sector and maintenance of the level of entity's financial activity it is advisable to design and implement a set of measures in audit and analytical direction that consists of the usage of financial and economic analysis tools, modern methods of financial audit. After all, in the process of financial and economic activity very often companies face with various types of fraud. Among them: financial fraud, employee misconduct, fraud and other risks that decrease financial results. Often, it is not enough to use standard audit methods to identify the nature of the risk since fraud is often a pre-planned and thought-out process that is accompanied by inventive measures to cover it.

Due to the conditions of an inappropriate control system, all of the above features can create a basis for various types of fraud. In particular, it enables company employees to distort data while displaying business transactions and reporting. Therefore, there is a need to introduce new techniques to detect fraud within the company and strengthen the system for detecting and blocking financial crimes by counterparties. An audit is a tool for ensuring the confidence of stakeholders in the disclosure of financial information about the activities of companies. Nowadays, audit development is taking place in several key fields of economic security: state audit, independent audit, internal audit. Regardless of the direction, one of the modern trends in the development is to ensure a high level of its social responsibility ((Popova et al, 2019). In addition, auditing is important for identifying economic security reserves because it is possible to analyze the formation of value chain management using it (Koval et al., 2019a).

Today, Ukraine is in the process of European integration and, according to article 51of the Partnership and Cooperation Agreements Ukraine (Verkhovna Rada of Ukraine, 2019) has made commitments to bring national legislation into line with EU legislation, particularly, in areas such as accounting and auditing. This stipulates the need to ensure a sufficiently high quality of audit services through standardization of conditions and requirements for certification of auditors.

Significant steps to strengthen the requirements for the quality of audit services and to increase the level of social responsibility of auditors were implemented through changes in the Ukrainian legislation that regulates independent professional audit, which contain a number of innovations concerning the regulation of audit activity, the most important of which are the following (Orlovska, Morozova, 2019): 
- $\quad$ new requirements for the procedure of auditors' certification are presented;

- $\quad$ reduced the number of auditors' registers from five to one - the register of auditors and entities;

- $\quad$ restrictions on the simultaneous provision of statutory audit and non-audit services to entities of public interest are identified;

- $\quad$ in addition to the existence of the Audit Chamber, the establishment of a Public Audit Oversight Body is planned. It will be responsible for regulating the quality of statutory audit services provided to public interest entities.

Thus, more strict conditions were created for obtaining an auditor's certificate for the right to audit, as well as standards for quality control in audit firms. The listed changes are necessary, significant in terms of enhancing the quality of audit requirements and creating a high level of social responsibility for entities of independent professional control. At the same time, they require serious adaptation to the new requirements of audit firms and practitioners.

Admitting the high level of dynamism and adaptability of the Ukrainian audit services market, it is necessary to acknowledge the inconsistency of a significant proportion of audit entities with the established criteria. The consequence is the withdrawal from the market of firms and auditors who have failed to comply with the quality requirements of the audit, which entitles them to carry out the statutory audit of the financial statements of economic entities, as well as audits of businesses of public interest. In general, this is reflected in the decrease in the number of entities and auditors in Ukraine in 2013-2017 (figure 1).

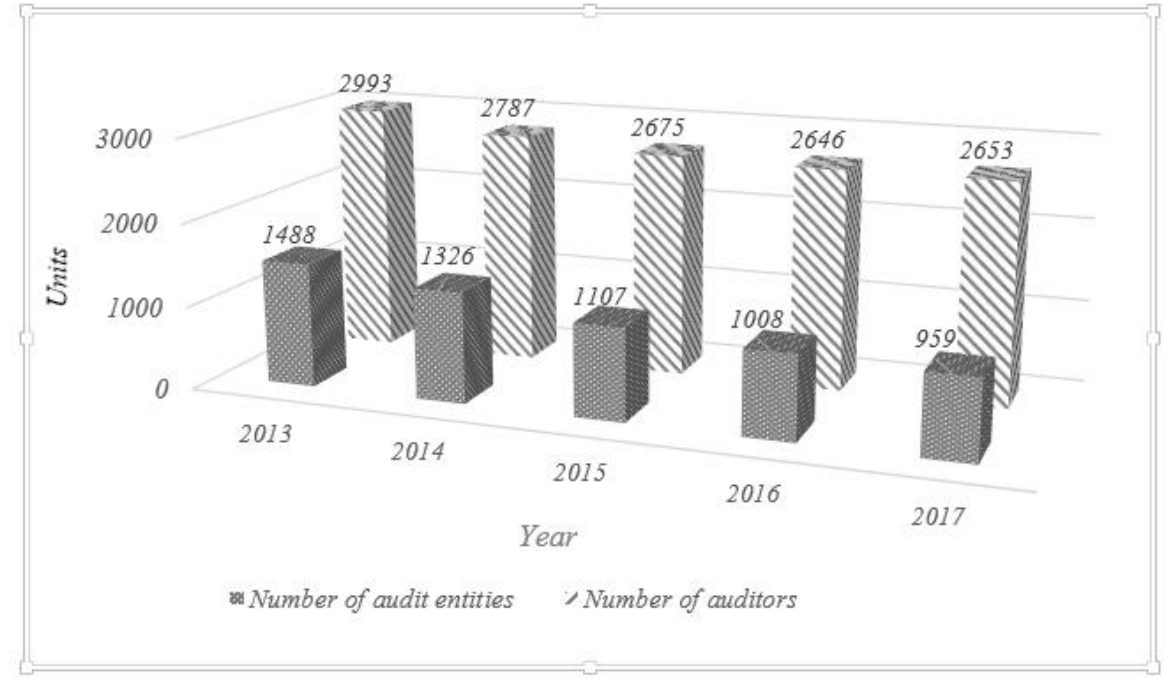

Figure 1. Dynamics of Audit Entities and Auditors in Ukraine in 2013-2017 Source: compiled by authors based on Audit Chamber of Ukraine (2017). 
Information on the number of auditors in 2013-2017 indicates a tendency for their reduction by 189 persons (12.7\%) and the number of auditors (by 340 companies or by $11.6 \%$ ), which indicates an outflow of auditors from the profession. At the same time, the analysis of the dynamics of the volume of services provided by audit entities in Ukraine in 2013-2017 as a whole shows the opposite dynamics. Thus, according to figure 2 a tendency for a gradual increase of this indicator over the studied period is displayed (figure 2).

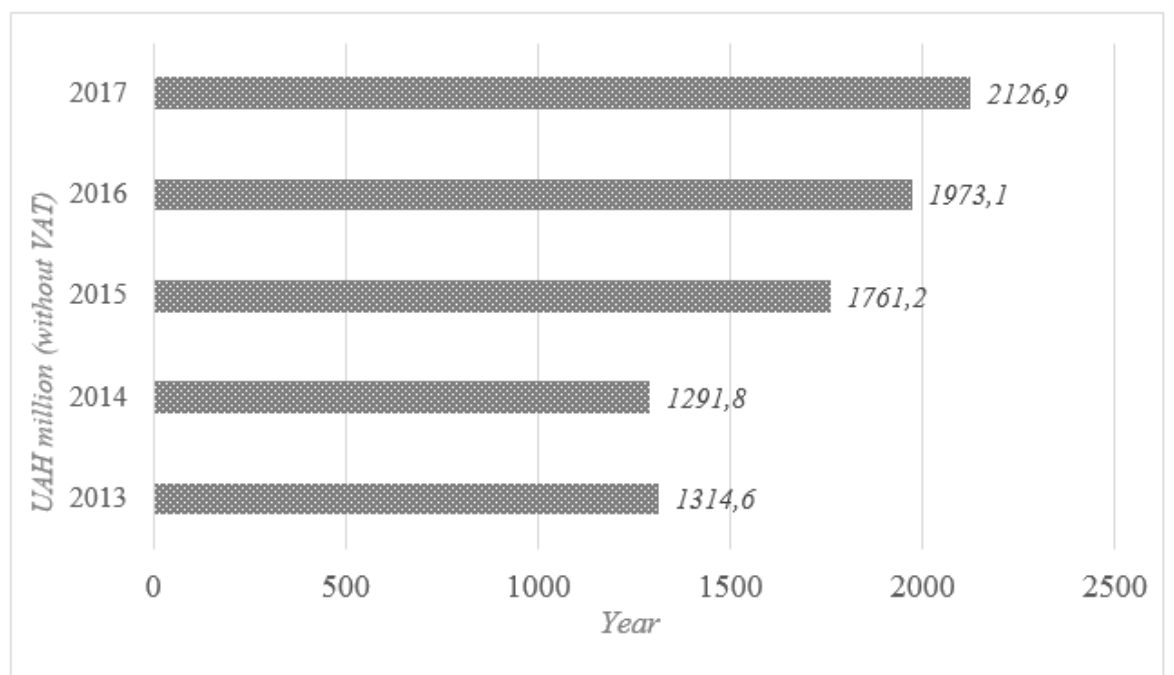

Figure 2. The volume of services rendered by the entities of audit activity in Ukraine in 2013 - 2017 without VAT, th. UAH

Source: compiled by authors based on Audit Chamber of Ukraine (2017)

In 2013-2017, the volume of services provided by audit entities reflected an increase of UAH 812272,2 thousand or $61.79 \%$, which is a positive indicator of the audit market development in Ukraine. The situation in the audit market has led to the fact that in 2017, the average income per audit entity estimated 2253 thousand UAH (excluding VAT), which is 1347.6 thousand UAH (without VAT) or 149\% more than the similar figure in 2013.

According to the expert's expectations and audit companies, the volume of audit services will continue to increase, which is caused not only by the objective demand for audit as a tool for improving economic security and creating a favourable investment climate in the country but also to a large extent by regulatory factors as a result expanding the listthe list of entities that are subject to mandatory annual audits, which will support the tendency in increasing the services that are provided by auditors.

The list of companies that are required to perform an annual statutory audit has increased since 2018. Today it includes enterprises operating in the extractive industries, banks, insurance companies, non-state pension funds, securities issuers that trade on the 
stock exchanges or for which a public offering is made, monopolies, public joint-stock companies, enterprises which are large and medium-sized, other financial institutions belonging to micro-enterprises and small enterprises, which have a common interest (Vivchar, Redkva, 2018). Positive expectations have also been generated regarding the volume of initiative audit services. It is expanding as foreign investments continue to flow to Ukraine, representations of international companies and various organizations carry out business activities, which, accordingly, implies an increase in the number of initiative audits, which allows to satisfy consumer needs through the use of marketing tools, for example, when attracting investments in various sectors of the material production of the economy (Koval et al., 2019 b).

At the same time, it should be noted that there is a correlation between these factors, because the provision of quality audit services builds investor confidence, stimulates the activity of non-resident economic entities and, as a consequence, increases the level of economic security of the state. In addition to foreign companies, more and more Ukrainian business owners are interested in conducting an audit and obtaining an independent opinion on the real state of doing business and ensuring economic security both at the micro-level of an individual economic unit and at the state level.

In addition to the independent professional audit, a significant determinant of the impact on economic security is the state audit, which is carried out by the authorized institutions in the financial control system of Ukraine. The state economic security ensuring depends on a certain extent of the consideration in the process of state audit of the peculiarities of the subjects of such audit, so the institutional structure of the audit should provide for the development of qualitative characteristics of its institutions, which would contribute to the development of the economic component of society. This requires the introduction of appropriate institutional changes in the organization and methodology of the audit. An important aspect of institutional change that needs to be taken into account in auditing is the interconnectedness of institutions; changing one of the institutions without taking into account the links in the institutional system will not allow an objective and impartial approach to the audit process.

The framing of the institutional foundations of a state audit is based on approaches to the activities of government institutions as a particular set of economic relations. These include relationships for the provision of current public needs, prospective public needs, and relationships that arise in the process of the government's activity as a dominant entity. Nowadays, public authorities and financial control (audit) agencies operate in Ukraine. These include the Ministry of Finance of Ukraine, the Accounting Chamber of Ukraine, the State Audit Service of Ukraine, the National Bank of Ukraine, the State Treasury Service of Ukraine, and others. 
The Accounting Chamber acts on behalf of the Verkhovna Rada of Ukraine to control the receipt of funds to the State Budget of Ukraine and their use. However, in many ways, the Accounting Chamber has common objects of control with the State Audit Service of Ukraine, but in general the scope of its powers is much broader, it extends to the Verkhovna Rada, the National Bank of Ukraine, the Antimonopoly Committee, executive bodies, bodies and institutions established under the legislation of Ukraine.

To balance and improve the quality of implementation of the legal and economic principles of auditing in the economic security system of the state, it is necessary to consider audit as a specific institution, which is a systemic entity that combines regulatory, organizational and methodological subsystems. The regulatory subsystem defines the set of financial and regulatory rules governing relations in the construction of an integrated system of financial audit, and the organizational and methodological subsystem unifies the entities of the audit by their functions and powers. This approach allows to determine the audit system mechanism of the state economic security of and to ensure its effectiveness.

To be dynamic and multidimensional, the audit process should be based on the following principles: regularity, the concentration of action and science. The principle of regularity implies that the audit is carried out cyclically, nature and control actions should be repeated at a fixed interval. The principle of concentration of actions implies the orientation of all audit control actions to achieve the main goal, the formation of the unified system of state financial control, its most essential content - to ensure the elimination of identified violations and prevent them from committing in the future.

The scientific principle is to organize the audit on a scientific basis, to ensure the integrated interconnections between the entities of the audit system within the national security of the state. The application of these principles will allow ensuring the effective functioning of the audit in the system of the state economic security. The effectiveness of control activities carried out by public financial control authorities in Ukraine can be assessed by a comparative analysis of the costs of maintaining them and the additional funds received from the budget from the activities. Thus, in 2017, UAH 1 spent from the state budget to support the activity of the Accounting Chamber of Ukraine amounted to UAH 3.4 thousand of audited funds. At the same time, each auditor checked on average almost UAH 1.8 billion of state funds, one auditor identified irregularities and deficiencies amounting to UAH 82.3 million (Accounting Chamber, 2017).

Due to the implementation of effective measures (inspections, audits, state audits) to compensate and recover losses incurred by the state for the results of 2016-2018, the overall efficiency of SASU in terms of the ratio of compensated losses of budgetary 
funds compared to expenditures for their maintenance of the institution was $131.9 \%$, which indicates the proper level of functioning of the public financial control body.

Table 1. Performance indicators of State Audit Service of Ukraine during 2016-2018

\begin{tabular}{|c|c|c|c|}
\hline Indicator & \multicolumn{3}{|c|}{ Years } \\
\cline { 2 - 4 } & $\mathbf{2 0 1 6}$ & $\mathbf{2 0 1 7}$ & $\mathbf{2 0 1 8}$ \\
\hline Maintenance costs, UAH million & 369,3 & 415 & 619,6 \\
\hline $\begin{array}{c}\text { Ratio of compensated losses of budgetary funds versus expenditures } \\
\text { for their maintenance, } \%\end{array}$ & 447,6 & 602,8 & 800,3 \\
\hline
\end{tabular}

Source: Compiled by authors based on State Audit Service of Ukraine (2018)

The state audit also serves as a preventive function in the economic security system of the country, as it prevents corruption, reduces the level of "shadowing" of the economy, and promotes more effective management decisions at the macro and microeconomic level. Assessing the work of public audit bodies in recent years, it can be assumed that the level of effectiveness of the organization of the process has increased significantly, but still, a considerable range of problems remain unresolved. Typical irregularities and deficiencies in the activities of audit entities include the following: inefficient spending of assets and assets; losses and lost profits; violations that cause the loss of resources and the illegal use of resources; violations that could result in further loss. To increase the positive value of the audit in ensuring the economic security of the state, organizations need to use alternative methods of business protection in addition to standard methods of auditing. Such audit services include forensics (financial investigations). Among the common causes of risk for a company are the weak corporate culture: an expanded IT system; the absence or non-implementation of certain procedures for hiring personnel; transfer of key functions to outsourcing companies without proper control over their performance; lack of the concept of "financially responsible person"; poor physical security; lack or excess of internal policies and procedures; the problem of company growth: the processes do not keep up with the business; lack of analytical data; lack of management accounting; a system of motivation that does not correspond to the realities of business, etc. (Araftenii, Bashynska, 2018).

Forensic, which is focused on detecting signs of financial fraud, is one of the methods of ensuring the national security of the country. Forensic services provided by auditing companies identify and capture signs of threats to economic security, as well as establish a cause and effect relationship between the factors and the causes that caused them and are the primary focus of the financial investigation. Investigation of financial crimes, incl. corporate, as an analytical and audit process, is characterized by 
organizational-methodological similarity and dynamic information. The organizational and methodological similarity is determined by the identity of the circumstances to be investigated in cases of the same categories (corporate intelligence, fraud risk management, IT forensics, etc.). The dynamic of information is affected by contradictions between known information about potential fraud and the ability to collect its evidence base, due to the particular situation of the financial investigation. The procedural financial investigation into financial fraud includes the following measures: a preliminary examination of the client's affairs; assessment of client relationship with counterparties and conflict verification; conducting surveys and questionaries; identifying and assessing deficiencies in the internal control system; performing analytical and intuitive procedures.

The negative effects of forensics are related to organizational mistakes, especially at the initial stage, as well as counteraction by stakeholders (executives, managers, accountants, financially responsible persons, etc.). The reasons that can cause the circumstances in which the likelihood of negative consequences is increasing, are the objective factors inherent in the whole control and analytical system in the current conditions of doing business.

Increasing of the effectiveness of the use of specialized audit, analytical, legal and knowledge in the field of modern information technology in financial investigations should occur in the direction of consistency, the tasks assigned to the forensic expert, the timely use of audit and analytical procedures to obtain evidence, where necessary the use evidence with people who are involved in the financial investigation of the tasks, techniques and results of the expert activities.

\section{Conclusions}

Today, the audit is an essential attribute of an open economy, as it forms the key components of its economic security, primarily at the micro-level. The realization of the positive impact of the audit on the economic security of the state is possible provided that its level of social responsibility is high, which reflects on the quality of audit services.

Several significant changes in the setting of stricter criteria for audit entities have affected their reduction, but as a consequence has improved the quality characteristics, personnel, methodological and managerial capacity. The institutional support of the state audit is investigated, the principles of its implementation for the economic security of the state are substantiated. The features of the implementation of the preventive function of a state audit in the system of economic security of the country are determined. The variability of audit services with a focus on practical inquiries can enhance the positive 
impact on improving the economic security of the state. One of the proposed tools is forensic, which is recommended for companies to minimize the risk of fraud, theft of assets and promote micro-level economic security.

\section{Aknowledgements}

The article presents the authors' results as part of a study conducted in 2017-2019 at the Kyiv National University of Trade and Economics at the request of the Ministry of Education and Science of Ukraine (The Praxeology of Analysis and Audit in the Economic Security System of Ukraine), state registration number 0119U100623).

\section{References}

Accounting Chamber (2017). Report of the Accounting Chamber for 2017. Retrieved from http://www.ac-rada.gov.ua.

Araftenii, A., \& Bashynska, M. (2018). Social point on the evaluation of accounting // Economics, Ecology, Socium, 2(3), 13-21. doi:10.31520/2616-7107/2018.2.3-2

Audit Chamber of Ukraine (2017). Report of the Audit Chamber of Ukraine to the Cabinet of Ministers of Ukraine for 2017. www.apu.com.ua. Retrieved from https://www.apu.com.ua.

Chen, C. (2011). Government Audit and National Economic Security. In: Dai M. (eds) Innovative Computing and Information. Communications in Computer and Information Science, 232. Springer, Berlin, Heidelberg.

Deb, R. (2018). Financial Audit or Forensic Audit? Government Sector Panorama // Indian Journal of Corporate Governance, 11(2),135-158.

Drogalas, G., Anagnostopoulou, E., Koutoupis, A., \& Pazarskis, M. (2018). Relationship between internal audit factors and corporate governance // Journal of Governance \& Regulation, 7(3), 13-17.

Fabiianska V. Yu. (2018). Forms to Express an Independent Auditor's Opinion according to the Results of Compulsory and Initiative Audit in Ukraine // Accounting and Finance, 2. 102-110.

Heritage Foundation. (2019). Heritage Foundation. Retrieved from www.heritage.org.

Hubarieva, I., Chmutova, I., \& Maksimova, M. (2016). Ukrainian economy unshadowing as a factor of state economic security management // Economic Annals-XXI, 159(5-6), 25-28.

Khovrak, I., \& Kozyarchuk, T. (2017). The impact of auditor's ethics on the quality of auditing the company's cash flows // Technology audit and production reserves, 1(4(39), 4-8.

Koval, V., Duginets, G., Plekhanova, O., Antonov, A., \& Petrova, M. (2019a). On the supranational and national level of global value chain management. // Entrepreneurship and Sustainability Issues, 6 (4), 1922-1937. https://doi.org/10.9770/jesi.2019.6.4

Koval, V., Kovshun, N., Plekhanova, O., Kvitka, S., Haran, O. (2019b). The role of interactive marketing in agricultural investment attraction // 19th International Multidisciplinary Scientific GeoConference SGEM 2019, 19(5.3), 877-884. https://doi.org/10.5593/sgem2019/5.3/S21.111

Koval, V., Slobodianiuk, O., \& Yankovyi, V. (2018). Production forecasting and evaluation of investments using allen two-factor production function // Baltic Journal of Economic Studies, 4(1), 219-226. doi:10.30525/2256-0742/2018-4-1-219-226 
Mazaraki A., Korolchuk O., \& Melnik T. (2010). Ukraine's economic security in the face of globalization challenges. KNUTE, Kyiv (in Ukrainian).

Meiss, K.-M., Naumik-Gladka, K., Krivtsova, T., \& Liadova, Yu. (2017). Improvement of public financial control in the context of ensuring financial security of the state. Economic Annals-XXI, 168(11-12), 63-68. DOI: 10.21003/ea.V168-13.

Moskalenko, N., Romanenko, O., \& Oliinyk, T. (2015). Approaches to enterprises' financial and economic security managemen // Economic Annals-XXI, 7-8 (1), 54-57. DOI:10.21003/ea

Nazarova, K., Zaremba, O., Kopotiienko, T., \& Mysiuk, V. (2018). Internal control system: sox-requirements approach to assessment // Financial and credit activity: problems of theory and practice, $4(27), 185-192$.

Orlovska, Y., \& Morozova, S. (2019). Innovation modernization of Ukraine's economy taking into consideration the EU's experience // Economics Ecology Socium, 3(2), 41-54. doi:10.31520/26167107/2019.3.2-5

Popova, O., Koval, V., Antonova, L., \& Orel, A. (2019). Corporate social responsibility of agricultural enterprises according to their economic status // Management Theory and Studies for Rural Business and Infrastructure Development, 41(2), 277-289. https://doi.org/10.15544/mts.2019.23

State Audit Service of Ukraine (2018). Public Report on the Activity of the State Audit Service of Ukraine for 2018. Retrieved from http://dkrs.kmu.gov.ua/kru/doccatalog/document?id=146550

Trusova, N., \& Klimenko, P. (2016). Building of socio-economic politics in the context of regional safety // Economic Annals-XXI, 157(3-4(1), 38-40.

Verkhovna Rada of Ukraine. (2019). Partnership and Cooperation Agreement between the European Communities (EU) and Ukraine. Retrieved from http://zakon3.rada.gov.ua/laws/ show/998_012. 